\title{
«I REMEMBER A MAHOMETAN STORY OF AHMED BEN EDRIS»: FREETHINKING USES OF ISLAM FROM STUBBE TO TOLAND*
}

\author{
«I REMEMBER A MAHOMETAN STORY OF AHMED BEN \\ EDRIS»: USOS LIBREPENSADORES DEL ISLAM DESDE \\ STUBBE A TOLAND
}

\author{
JUSTIN CHAMPION \\ Royal Holloway, University of London
}

This paper explores the intellectual context and learned sources of an unnoticed clandestine manuscript owned by Charles Hornby in 1701 which included a version of Henry Stubbe's controversial Account of the rise and progress of Mahometanism and a translation of the first seven chapters of a Spanish work of Muhammad Alguazir (fl. 1610) Apología contra la ley Cristiana. The paper sets out to examine how both freethinking figures like Stubbe and Toland and orthodox men of learning encountered, used and challenged Islamic anti-Christian polemic. To this end it establishes the diverse patterns of citation and usage of «orientalist» erudition between 1650 and 1720 -focusing in particular on the great works of Hottinger and Pococke. The paper argues that freethinkers were very capable of appropriating both Christian erudition and Islamic
Este artículo explora el contexto intelectual $\mathrm{y}$ las fuentes eruditas de un manuscrito clandestino, que ha pasado inadvertido hasta la fecha, que en 1701 pertenecía a Charles Hornby y que incluía una versión de la obra polémica de Henry Stubbe Account of the rise and progress of Mahometanism, además de una traducción de los siete primeros capítulos de la obra en castellano de Muhammad Alguazir (fl. 1610) Apología contra la ley Cristiana. El artículo propone examinar cómo las polémicas islámicas anticristianas fueron encontradas, utilizadas y cuestionadas, tanto por personajes librepensadores, como Stubbe y Toland, como por los estudiosos más ortodoxos. Para tal fin establece los distintos hábitos en la citación y utilización de la erudición "orientalista" que se emplearon entre 1650 y 1720 , prestando especial atención a las grandes obras de Hottinger y Pococke. El artículo argumenta que

* Martin Mulsow, Jonathan Israel and Patricia Crone kindly invited me to participate in a colloquium on "Radical Islam and freethinking" at Princeton Advanced Institute which prompted this paper. The discussions and conversations at that meeting were of great value in refining this contribution. I am grateful to Humayun Ansari and Francis Robinson for advice on further reading. Many thanks to the editors of the journal and to the anonymous referees for their constructive and helpful comments. 
theology (in particular that hostile to Pauline corruption of doctrine and scripture) to their irreligious ends.

Key words: Orientalism; Erudition; Ahmed ben Edris; Shihāb al-Dīn Muḥammad b. Idrīs al-Shāfíī; al-Qarāfī; Henry Stubbe; Edward Pococke. los librepensadores fueron perfectamente capaces de apropiarse de aspectos tanto de la erudición cristiana como de la teología islámica (en particular la que criticaba la corrupción paulina de la doctrina y las escrituras sagradas) para sus fines antireligiosos.

Palabras clave: orientalismo; erudition; Ahmed ben Edris; Sihāb al-Dīn Muhammad b. Idrīs al-Šāfíî; al-Qarāîi; Henry Stubbe; Edward Pococke.

There is, in a little examined volume now held in the University of London special collections, a remarkable passage (underlined in red pencil for emphasis) describing the Prophet's mission. The probable author, Henry Stubbe (d.1676?) republican controversialist, wrote, «I believe that he was a convert to the religion of the Judaizing Xtians \& did form his religion as far as possible in resemblances of theirs. They \& the Arrians were his principal instructors - but not any of them had any hand in the penning of the Alcoran». ${ }^{1} \mathrm{Al}-$ though there were significant medieval precedents for the claim, the suggestion that Islam grew out of early Christianity, had become with the rise of anti-Trinitarianism within Christian confessions, a powerful threat to commonplace theological assumptions in Europe. ${ }^{2}$ To articulate such a claim, especially in a commendatory way, required considerable intellectual bravery, especially in an environment which was fundamentally prejudiced against Islam. Such a case also required erudition both in the author and readers, especially since it meant often reworking already existing polemical discourses. At the very least a working knowledge of both the history of the early Church and the historical circumstances and traditions of the rise of Islam was necessary. This knowledge might be derived from the encounter with works of learning (both oriental and occidental) coupled with a willingness to read with innovative, or at least unusual, intentions in mind, or by direct engagement with

${ }^{1}$ Senate House University of London, Mss 537, fol. 120. The story of how the mss. came to the collection can be deduced from the fact that it bears the bookplate of the Rev. John Disney, D.D. (sold at Sotheby's in 1817). It came to the university of London collection as a gift of New College, Hampstead in 1960.

${ }^{2}$ For a general overview of the pre-sixteenth century traditions, see Daniel, N., Islam and the West, Edinburgh, 1960. 
Muslim communities. Importantly for the purpose of exploring the encounter with Islamic traditions the manuscript was bound with a work entitled «An epistle from Achmet Ben Abdalla a learned Moor concerning the Xtian religion». This was a scribal copy of a work of genuine Muslim theological polemic - G.A. Wiegers has established that the Latin text (and the English transcription which concerns us here) derives from the first seven chapters of a Spanish work of Muhammad Alguazir (fl. 1610) Apología contra la ley Cristiana, with the addition of a new preface outlining the circumstances of authorship. ${ }^{3}$ Derived from the apologetic writings or «creeds» of Muhammad al-Sanūsī (d. 897/1490) it was composed by Alguazir (a Morisco intellectual) at the request of Mawlāy Zaydān «the very powerful, virtuous helper, and very lofty, righteous, sublime King and Ruler of the Muslims».. ${ }^{4}$ It has received little attention from historians of seventeenth century European intellectual history. A Latin version of the work, produced by Aubert de Versé, is held in Archbishop Tenison's papers at Lambeth Palace and dates to 1682, and may well be the source for the translation. ${ }^{5}$ Chetham's Library in Manchester holds another English copy (possibly dated to 1664). ${ }^{6}$ Like the exchange, circulation and commentary, of material connected to the Gospel of Barnabas, which arguably had Morisco ori-

${ }^{3}$ Wiegers, G.A., "The Andalusi heritage in the Maghrib: the polemical work of Muhammad Alguazir (fl. 1610)", in O. Zwartjes (ed.), Poetry, Politics and Polemics. Cultural transfer between the Iberian Penisula and North Africa (Orientations, 4), Amsterdam, 1996, 107-132. See also Wiegers, G.A., "European converts to Islam in the Maghrib and the polemical writings of the Moriscos", in M. García-Arenal (ed.), Conversions islamiques. Identités religieuses en Islam méditerrenéen, Paris, 2002, 207-223.

${ }^{4}$ Wiegers, "The Andalusi heritage", 110-111, 114.

5 The Lambeth Palace, Todd Catalogue has the following description: «MS 673 Codex chartaceus, in folio»s. This volume, entitled Systema Theologicae Socininae, consists of the «original papers, which a Cabal of Socininans in London offered to present to the Embassador of the King of Fez and Morocco, when he was taking leave of England in 1682. The said Embassador refused to receive them after having understood that the concerned religion. The Agent of the Socinians was Monsieur de Verze». I am very grateful to Jessamy Sykes for this information. Martin Mulsow is currently exploring in more detail this episode: see Mulsow, M., "The 'new Socinians': intertextuality and cultural exchange in Late Socinianism", in M. Mulsow and J. Rohls (eds), Socinianism and Arminianism. Antitrinitarians, Calvinists and Cultural exchange in seventeenth Century Europe, Leiden, 2005, 49-78, 57-60.

${ }^{6}$ See Chetham's Library, Manchester, Manuscripts Catalogue, A.2.41 “An epistle of Ameth Benandala, a mahumetan to the Prince of Orange, Count Maurice and to Emanuell, Prince of Portugal". 
gins, amongst cosmopolitan freethinking communities in the early eighteenth century but in particular by John Toland and Prince Eugen of Savoy, the absorption and adaptation of these type of Islamic arguments and traditions was complex and challenging. ${ }^{7}$

These fragments might properly be regarded as product of a dominant Christian «orientalism» calculated to present Islam in a pejorative way. Alternatively, in their recovery and display of Islamic traditions and voices, they could also be characterised as scholarly and antiquarian rather than weapons of oppression. The binary alternative between categorising these texts as disinterested erudition or ideological instruments of empire, as will be argued, do not allow a cogent account of their origins and significance. The debate over the intellectual purchase of Edward Said's account of the history and nature of «orientalism» has been recently rekindled by Irwin's narrative of «scholarly» achievements from the medieval to the modern. In describing the progress of seventeenth and eighteenth century «eastern wisdom», Irwin claims to have established that the writings of men like William Bedwell, Edward Pococke, Ludovico Marracci and Barthelemy D'Herbelot —although perhaps shaped by theological prejudice- were disinterested engagements with texts and languages. ${ }^{8}$ Such pure scholarship was uncontaminated either by motives related to the oppression of the East, or indeed by more local political concerns or objectives.

Anxious to refute the ideological perspectives of Said's work, Irwin has overly insulated the world of early modern erudition from

\footnotetext{
${ }^{7}$ John Toland was the main actor in this distribution having had access to the Italian manuscript of the Gospel of Barnabas through his intimacy with Prince Eugen of Savoy's library in Vienna. He circulated both a scribal and printed account of the tradition - arguing in a similar vein to Stubbe for a convergence of Islamic and Christian faiths: for a discussion, see Champion, J.A.I. (ed.), "Introduction", in John Toland's Nazarenus, Oxford, 1999, 1-106; for the debate about the Morisco origins of the material see Bernabé Pons, L.F., El texto morisco del Evangelio de San Bernabé, Granada-Alicante, 1998, and idem, El Evangelio de San Bernabé: un evangelio islámico español, Alicante, 1995; idem, "Los mecanismos de una resistencia: los libros plúmbeos del Sacromonte y el Evangelio de Bernabé", in M. Barrios Aguilera and M. García-Arenal (eds.), Los Plomos del Sacromonte: invención y tesoro, Valencia-Granada-Zaragoza, 2006, 385-402; for a discussion of the manuscript traditions, see Joosten, J., "The 'Gospel of Barnabas' and the Diatessaron", The Harvard Theological Review, 95 (2002), 73-96.

${ }^{8}$ Irwin, R., For lust of knowing. The Orientalists and their enemies, London, 2006. See also Harvey, L.P., "British Arabists and Al-Andalus", Al-Qanțara, 13 (1992), 424436.
}

Al-Qanțara (AQ) XXXI 2, julio-diciembre 2010, pp. 443-480 ISSN 0211-3589 
the intellectual cut and thrust of its times. As many accounts of early modern scholarship and learning establish - erudition (whether patristic, literary, biblical, philosophical or classical) was profoundly embedded in a variety of political cultures and institutions. The consequences of Irwin's unwise detachment of works of oriental learning from the possibilities of political or religious utility can be briefly reviewed in the publication history of Edward Pococke's translation of the twelfth century work by Ibn Tufayl Hayy ibn Yaqzān into the Latin Philosophus Autodidactus in $1671 .{ }^{9}$ Once released into a Latin edition the original Arabic work was subsequently translated into English three times in the following forty years — once by a Quaker, George Keith (1674); once by a Non-Juror, George Ashwell (1686) and again by the Anglican Simon Ockley under the title The improvement of human reason (1708). ${ }^{10}$ Each of these works delivered a different account of the significance of the original text adapted to the specific theological understanding of the capacities of human reason - the Islamic text is valued for its theological perspicuity and for the authority it brought to each editor's objectives. Recovering an authentic Islamic perspective is secondary to reinforcing pre-existing theological positions. Once technical scholarship had opened such texts to a wider audience by translation they became intellectual and rhetorical stockpiles for other purposes.

In the context that this paper sets out to explore, neither Said's view of orientalist discourse as a blunt weapon of power, nor Irwin's counter-suggestion of impartial learning are effective explanatory devices. Counter-intuitive as it may seem, both seemingly contradictory positions can be seen at work. The figures examined here - Stubbe and Toland in particular (neither of who are mentioned by either Said or Irwin) — were minority voices arguing for a radical revision of contemporary orthodoxies. As will be argued, they saw opportunity in using Islamic arguments and texts as instruments to be wielded against the dominant forms of political and religious power. In this view then «orientalist» discourses were conceived of as useful

\footnotetext{
${ }^{9}$ Irwin, For Lust of Knowing, 96-97, which discusses the 1671 translation without any reference to the subsequent editions.

${ }^{10}$ Russell, G.A., "The impact of Philosophus autodidactus: Pococke, John Locke and the Society of Friends", in G.A. Russell (ed.), The 'arabick' interest of the natural philosophers in seventeenth-century England, Leiden, 1994, 224-65.
} 
weapons of the weak against Christian orthodoxy. Explaining how this was possible will require establishing what might be called the public «charisma» of orientalist learning. Freethinkers understood that the authority of the learned texts they used made them valuable elements in public debate - citing an Islamic theologian from the twelfth century, or from a Muslim anti-Christian polemic of the early seventeenth century, somehow accrued credibility and significance to their arguments. How this intellectual process of transmission and usage of Muslim ideas and arguments worked amongst this radical freethinking milieu will be the more general theme pursued here.

That both of these works were copied and circulated amongst heterodox circles from the 1670 s until the 1700 s provides a casestudy for how freethinking readers in the republic of letters encountered and made sense of Islamic traditions and polemic. ${ }^{11}$ The historical circumstances of this exemplar allow an exploration of precisely how the encounter with Muslim sources and traditions took place, but also what meaning was made out of the encounter. The annotation on the inner leaf records (alongside the words, «Worship, worship, worship») its owner as «Charles Hornby» and dated to «January 3rd 1701». Internal evidence suggests that Hornby copied it from another exemplar: there are a series of corrections, crossing through and marginal markings. The underlining in different coloured pencils, the intrusion of running heads, chapter titles, and cross references suggests either a process of collation for an edition, or possibly preparation for a printed version. ${ }^{12}$ Parts of the manuscript suggest that Hornby carefully compared the first item with other (printed) sources -in particular Charles Blount's published works. ${ }^{13}$ This version of Stubbe's work was «the best and earliest dated copy known» of the text. ${ }^{14}$ The evidence of other

${ }^{11}$ Champion, J.A.I., The pillars of priestcraft shaken, Cambridge, 1992, chapter 5.

12 See SH Mss 537, fol. 107, «Vide Blue Book 123 chap. 8 \& 9»; fol. 113 «wanting here from fol 165 to fol. 169 in blew book». The margins include both + and * marks identifying specific passages. Latin and Greek phrases, as well as references to other books are also included in the margins.

13 See SH Mss 537, fol. 3 where he notes «Blount has copied this in his Oracles of Reason fo. 159»; fol. 11 «Blount go's on again in the same letter»; SH Mss 537, fol. 38 «Blount has copied this in a letter to Hobbes \& ye 2 pages \& a half past»; SH Mss 537, fol. 42 «v. Blount fo. 104».

${ }^{14}$ See the early edition (privately published under the auspices of the Islamic Society) undertaken by H.M.Kh. Shairani: Stubbe, H., An Account of the Rise and Progress of 
extant copies suggests it was circulated in a number of literary forms. Certainly the republican suicide Charles Blount (d. 1693) was involved in distributing scribal copies, as well as incorporating fragments of the text in his own printed works in the early $1690 \mathrm{~s} .{ }^{15}$ It is clear then that the intellectual milieu which shaped the form of this particular copy was heterodox rather than pious: Hornby must have had access to the writings of Blount and others to have been able to make his own annotations. The fact that he added a copy of the second work allows further consideration of the potential radical readings of the meaning of Islamic traditions.

Charles Hornby (d. 1739) was a moderate Whig with commitments to the Hanoverian succession, who by the fact of his ownership may tell us much about the latent freethinking character of such circles. Hornby was in many ways an unexceptional man, a civil servant with increasingly lucrative employment in the Pipe Office from $1700-$ a bureaucratic role that involved preserving the record of the royal income, arranged by county, for each financial year. ${ }^{16}$ His political moderation is best indicated by his promotion under Robert Walpole's ministry in 1730 to second in command of the Pipe Office. In an age where party politics was reflected in the achievement of «place» the fact that he remained in office for nearly four decades suggests he was both politically connected and flexible in his allegiances. He considered himself a learned man - pub-

Mahometism, with the Life of Mahomet, London, 1911, viii. This edition was reprinted in Lahore, 1954. The manuscript was subsequently sold in the A catalogue of the entire and genuine collection of the learned and curious Charles Hornby, London, 1739. The British Library holds four copies: Ms Sloane 1709 "History of the Saracens"; Sloane 1786 "Fragment of a treatise"; Harl. 1876 the original; Harl. 6189 (copy of Harl. 1876) dated 1718. An annotated copy (MS Eng misc c309) is in the Bodleian Library, Oxford.

15 Jacob, J.R., Henry Stubbe, Radical Protestantism and the Early Enlightenment, Cambridge, 1983; Champion, J.A.I., "Impostors, Legislators and Republicans: the English context of treatise on imposture in the late seventeenth century", in S. Berti, F. Charles-Daubert and R.H. Popkin (eds.), Heterodoxy and Irreligion in Early Modern Europe, Leiden, Klewer, 1995, 333-356. See more recently Birchwood, M., "Vindicating the Prophet: universal monarchy and Henry Stubbe's biography of Mohammed", Prose Studies, 29 (2007), 59-72.

${ }^{16}$ Chamberlayne, E., Anglice notitia: or the present state of England, London, 1702,544 , he became deputy attorney in 1702; Morgan, J., The new political state of Great Britain, London, 1730, 330. On the Pipe Office's role see Lady Stenton, "The Pipe Rolls and the Historians, 1660-1883”, Cambridge Historical Journal, 10 (1952), 271-292. 
lishing corrections of William Dugdale's Baronage. ${ }^{17}$ He sponsored by financial subscription the publication of learning by men like Thomas Hearne, Henry Spelman and Gilbert Burnet, as well as an «harmony» of the gospels in $1720 .{ }^{18} \mathrm{He}$ also engaged in political writing - producing a flurry of pamphlets between 1712-1713 under the title $A$ caveat against the Whiggs. These exposed his hostility to the radical commonwealth Whigs, while promoting a «country» anxiety about the corruption of liberties by the Court. The first of his advices to the Freeholders of England (1715) optimistically contrasted Whig liberties with Tory tyranny; the second iteration of 1722 bemoaned how ministerial corruption threatened the constitution. ${ }^{19}$ Insight into Hornby's religious dispositions and convictions can be gained from two later pamphlets - one addressed to the recalcitrant rector of Fryerning, and the other concerning a bitter dispute between himself and the vicar of Ingatstone. Both works expose a bitter seam of Erastian hostility to the craft of the «modern priesthood». ${ }^{20}$ How far these ideological positions were shaped by, or provoked, his encounter with this manuscript is difficult to determine.

Together the two works represent odd bedfellows, but arguably, underpin a radical perspective on the relationship between Islam and Christianity. In the manuscript it is possible to see the combination of a neutral insight into the history of Islamic culture and history, and the «interested» use of that knowledge which pre-dates the eighteenth century achievements of Boulainvilliers and others. ${ }^{21}$ Stubbe's work constructs an unusual representation of Islamic theological traditions and the specific historical rise of the Prophet. The second, reproduces a standard Islamic anti-Christian polemic against the Trinity and idolatry which had itself a tradition of circulation

${ }^{17}$ Hornby, C., A small specimen of the many mistakes in Sir William Dugdale's Baronage, London, 1730, and subsequent dissertations in 1736 and 1738.

18 See 1720 Harmony, J. Coren (ed.); Thomas Hearne's edition of Robert of Avebury (1720); and in 1723 works of Sir Henry Spelman and Gilbert Burnet.

${ }_{19}$ English advice, to the freeholders of England (John Roberts, 1715) and The second and last English advice, to the freehoulders of Englane [sic] (1722).

${ }^{20}$ Hornby, C., A letter to the Rector of Fryerning, London, 1732, and idem, An appeal to common sense and common honesty, in a few letters and papers, London, 1736. Hornby's dispute in Fryerning over tithes involved him in a legal case with Robert d'Oyly see The National Archives, E134/4Geo2/East8.

${ }_{21}$ Israel, J.I., Enlightenment contested, Oxford, 2006, 615-48. 
now evident in two Spanish manuscripts —one in the National Library at Madrid, and one in Wadham College Oxford. ${ }^{22}$ An Arabic original does not appear to have existed. A further Latin text (based on the Alguazir fragment, but with some expansions) was in John Selden's collection now in Oxford (Ms Arch Selden B 8) and was the source for the 1705 Rostock printed edition. The latter (and possibly the Lambeth Mss.) may have originated in an edition prepared earlier in the seventeenth century by the Dutch Arabic scholar Thomas Erpenius. ${ }^{23}$ The Rostock edition, prepared by Zachery Grape, records (as does the 1712 work of La Croze which cites passages in English) that the work was transcribed by Mr Goetz of Leipsick, "who copy'd it at Oxford, and communicated it to Grape». ${ }^{24}$ Hornby's copy, dated 1701, predates all these examples with the exception of Selden's and the copy in Lambeth. ${ }^{25}$ Clearly the precise textual relationship between these different manuscripts requires further research to establish the circuit of intellectual community and transmission. What is quite clear, however, is that each «version» (Spanish mss., Latin mss., Latin printed, English mss. and English printed) has its own distinctive form; the text was subjected to bespoke appropriation for particular circumstances and specific audiences across the century or so of its circulation.

It is worth briefly outlining the arguments of the «Epistle» which derived from the tradition of munäzara (or public religious debate). Addressed to a Christian (who might read without «prejudice or affectation») it focused on the nature and prophethood of Christ and presented «what wee Moors thought of our Lord Jesus Christ?». ${ }^{26}$ The text dealt with the «irreconcilable clash between Islamic no-

${ }^{22}$ Here I rely on Harvey, L.P., "A second Morisco manuscript at Wadham College, Oxford: A.1815”, Al-Qanțara, 10 (1989), 257-272, which includes a brief page by page description of the mss.

${ }^{23}$ Wiegers, "Andalusi heritage", 122-123; Grapius, Z. (ed.), Ahmad b. 'Abd Allāh, Ahmet Ben-Abdala, Mohammedani Epistola theologica de articulis qvibusdam fidei, Rostochi, Typis Nicolai Schwiegerovii, 1705.

${ }^{24}$ Reflections on Mahometanism and Socinianism, London, 1712, 185.

25 There are reasons for thinking that the English version does not derive from the Selden Mss, especially the final passages at the end of the treatise; see Wiegers, "Andalusi heritage", 125.

${ }^{26}$ Powell, A.A., "Muslim-Christian debate: the medieval legacy of munazara", in Muslims and missionaries in pre-mutiny India, London, 1993, 6-42. I am very grateful to Francis Robinson for this reference. 
tions of tauhid (divine unity) and Christian understandings of [...] taslis (Trinity)». ${ }^{27}$ Despite recognising that «he is anointed a prophet and Messenger of God», the text argued for the impossibility of treating Christ as a son of God «brought forth by a miracle of Almighty God». Citing Muslim Quranic commentary on the unity of God the case was proved by citation from the Old and New Testaments. The author's objective was so «I may publish \& explain that most exalted word of truth, which although brighter than the sun, is yet obscur'd in the North part of the world by the darkness of Interpreters \& for want of a true sense of the holy scriptures». ${ }^{28}$ The idiom of enlightenment exposing the failings of the kingdom of darkness connected well with freethinking aspirations for the reform of contemporary Christianity. Premised on the conviction that there is «one only God», the work outlined metaphysical and scriptural objections to the Trinity as the «greatest» error. Using an epistemological argument, subsequently to be exploited by Christian antitrinitarian authors, the text insisted on the fundamental incomprehensibility of the doctrine: «For no human intellect can perceive or understand how one and the same can bee Father, Son \& Holy Ghost in one sole essence \& at one \& the same time». The «Epistle» critiqued the corrupted Aristotelian language of «persons», «hypostases», and «essences» underpinning false Christian doctrine, in much the same way as Hobbes' had done in book IV of Leviathan. Christians misunderstood the rhetorical language of Scripture: to refer to Christ as the «spirit» of God was not to claim «external generation». ${ }^{29}$ Adopting commonplace arguments to expose the absurdity of Christian doctrine (could Mary's womb contain the infinity of God; was the crucifixion a form of self-harm?) the author also condemned the extremes of Jewish accounts which dismissed Christ as an «impostor» and the God of the Christians. The Qur'ān promoted a «middle way» —Judas, «his figure being changed into the figure of Christ», was crucified in his stead; Christ «was neither dead nor crucified but translated». ${ }^{30}$

27 Powell, "Muslim-Christian debate", 20; see Matar, N., "Anglo-Muslim Disputation in the Early Modern Period", in M. Birchwood and M. Dimmock (eds.), Cultural encounters between East and West, 1453-1699, Amersham, 2005, 29-43.

${ }^{28}$ SH Mss 537, “An epistle”, fol. 1.

${ }^{29}$ Idem, fols. 7-8.

${ }^{30}$ Idem, fols. 14-17.

Al-Qanțara (AQ) XXXI 2, julio-diciembre 2010, pp. 443-480 ISSN 0211-3589 
The «Epistle», in a standard polemical move, dismissed the singular truth of the Christian message by pointing to the variety of conflicting Christian confessions. The differences between Calvinist, Lutherans, Anabaptists and Catholic, when compared with the dominance of Islam «from ye River Ganges \& the East Indies even to Hungary \& Greece», gave clear evidence of the providential underwriting of Islamic truth. The tradition of tahriff (by close reading of Scripture) undermined the textual integrity of revelation. Since Christ left no books, writings or precepts, «the Gospels are nothing else but the History of Christ» composed by errant human penmen. Since the gospels were written by variable human authority they were unreliable and contradictory: «none of them contain any precept or doctrines concerning glory, hell or Laws divine or human». The treatise deployed the standard scholarly distinction between

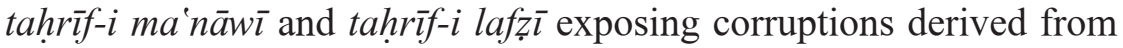
improper interpretation of linguistic meaning, and false doctrine prompted by faults in the textual traditions. Importantly this scriptural instability meant that whereas the «Holy Alcoran» pronounced the Law of God for society, «the law of the Christians was ordained by man». ${ }^{31}$ Christ was God's prophet, messenger and creature, but the Christian tradition had suppressed the prophecy of Mohammed. Specifically, John 14, which promised the «paraclyte or comforter» had been erased by corrupt Christian clergy. ${ }^{32}$

The «Epistle» delivered a comprehensive version of a standard Islamic anti-Christian polemic. It was a classical example of the intellectual world of the seventeenth century Morisco diaspora composed for two different readerships - a Christian audience whom it might convert; and a Muslim readership whom needed their Islamic commitments reinforced. ${ }^{33}$ Bound in Ms 537 —alongside Stubbe's «Account»- the work reached a different (and unintended) audience comprised of English men and women, some probably convinced Christians, some perhaps wavering in their confessional commitments, but all (without doubt) not Muslims. Both works in-

${ }^{31}$ Idem, fol. 20.

${ }^{32}$ Idem, fols. 2, 21. Most notably, this argument was used deliberately in the clandestine De tribus impostoribus, see Schroder, W. (ed.), De Imposturis religionem (de tribus impostoribus), Stuttgart, 1999, 128.

${ }^{33}$ For a recent overview see Harvey, L.P., Muslims in Spain 1500-1614, Chicago, 2005 .

Al-Qanțara (AQ) XXXI 2, julio-diciembre 2010, pp. 443-480 ISSN 0211-3589 
dependently, and combined as they are in the volume, offer a fundamental and heterodox critique of both historical and contemporary Christianity. The works have different ambitions. Stubbe's account, deploying a series of erudite sources, proffered an unorthodox perspective on the historical relationship between Judaism, Christianity and Islam. The «Epistle» gave vernacular voice to a standard Muslim anti-Christian polemic. Some reflection on how the two texts interacted for its early eighteenth century audience is appropriate. Read by the heterodox already predisposed to be hostile to Christianity it provided a useful arsenal of philosophical and textual arguments which might be keenly adapted to occidental purposes. The process by which this happened is complex.

Historians have shown that the opportunities to read and study the voices of Islamic thought (through translation into a European idiom, whether vernacular or Latinate) after the $1620 \mathrm{~s}$, were manifold. ${ }^{34}$ However, as was the case with other types of non-Christian confessional writings, the reception of Islamic texts produced both orthodox and heterodox responses. The processes by which a series of anti-Christian polemics produced by the Jewish community were appropriated by non-Jews to construct critiques of organised religion have been examined in detail. ${ }^{35}$ With specific works, networks of transmission can be traced from initial scribal circulation to subsequent printed texts, and later vernacular translations in the eighteenth century. Freethinkers deeply involved in the circulation of clandestine works, like Anthony Collins, undertook this type of cultural transaction. So for example, Montalto's work on Isaiah was translated in 1790 by «Philo-veritas» as a critique of intolerant Christianity; the works of Orobio and Mortera were edited into the 1770 Israel Vengé. The attraction of these works for impious readers was that much of the polemic in such works involved detailed and

${ }^{34}$ Feingold, M., "Oriental studies", in N. Tyacke (ed.), The history of the University of Oxford, volume 4: Seventeenth-century Oxford, Oxford, 1997, 449-504; Toomer, G.J., Eastern Wisedome and Learning: the study of Arabic in seventeenth-century England, Oxford, 1996.

${ }^{35}$ Popkin, R.H., "Jewish anti-Christian argument as a source of irreligion from the seventeenth to the early nineteenth century", in M. Hunter and D. Wootton (eds.), Atheism from the Reformation to the Enlightenment, Oxford, 1992, 159-181; see also Hulen, A.B., "The 'Dialogues with the Jews' as sources for the early Jewish argument against Christianity", Journal of Biblical Literature, 51 (1932), 58-70. 
hostile textual criticism of the Old and New Testaments which might be readily redeployed into contemporary debate. Similarly men like Blount and others exploited writings from the early Christian Church which engaged in polemical debates with «pagan» authors like Celsus and Porphyry about the authenticity of scriptural evidence for core Christian doctrine like the incarnation, crucifixion and resurrection. ${ }^{36}$ As Adam Sutcliffe notes, eighteenth century heterodox authors turned to «plagiarism, tendentious translations, and authorial ventriloquism or anonymity» to make their points. ${ }^{37}$ It was possible to «turn» forms of confessional polemic against different contemporary religious institutions: thus the expository, argumentative, and denunciatory modes of inter-confessional polemic might be used out of original context. Earlier critiques, whether Porphyry's extensive arguments exposing contradictions in the New Testament (especially in relation to the variant accounts of Christ's genealogy or his reputation as a magician), or the Jewish critique of Christianity under Islamic rule in the middle ages, might all be recycled for new contexts. ${ }^{38}$ The specific evidence of textual encounter, translation and appropriation explored in this contribution will give some concrete examples of this process of cultural translation.

Textual and linguistic preconditions, as well as transmission networks, underlay the framework for material access to these «oriental» ideas. Flexibility of intellectual disposition was also implied. Readers needed to be capable of «translating» Muslim conceptions and arguments into a discourse appropriate for comprehension by Christian audiences. A first context for understanding Hornby's encounter was the development, over the seventeenth century, of more sophisticated attitudes to and encounters with «other» religions in general, and Islam in particular. ${ }^{39}$ By the 1700 s, the possibilities of

${ }^{36}$ Hargis, J.W., Against the Christians. The rise of early anti-Christian polemic, New York, 2001, 19, 37, 64, 91.

37 Sutcliffe, A., "Judaism as the anti-religion", Journal of the History of Ideas, 64 (2003), 105.

38 Hulen, "The 'Dialogues with the Jews"”, 58, 61; and Lasker, D.J., "Jewish critique of Christianity under Islam in the middle ages", Proceedings of the American Academy for Jewish Research, 57 (1990-1991), 121-153.

39 Pailin, D.A., Attitudes to other religions: comparative religion in seventeenth-and eighteenth-century Britain, Manchester, 1984; Harrison, P., 'Religion' and the religions in the English Enlightenment, Cambridge, 1990; Jacob, M.C., Strangers Nowhere in the World: The Rise of Cosmopolitanism in Early Modern Europe, Pennsylvania, 2006. 
literary and physical conversation with the «other» were manifold. ${ }^{40}$ Those men and women connected to the intellectual elite - the self named «republic of letters»- had many material opportunities for engaging with non-Christian cultures as is illustrated in the case of Lady Mary Wortley Montague. Writing in April 1717 from Belgrade to the Abbé Conti, Lady Mary described her «intimate daily conversation» with a learned Effendi Achmet-Beg which had given her the «oportunity of knowing their religion and morals in a more particular manner than perhaps any Christian every did». Conducted over a three week period, this brief friendship enabled a review of the differences between Christian and Muslim, as well as the discussion of a variety of sects in both religions. Achmet Beg suggested that if Lady Mary read the Qur'ān in its original language she would find the «purest morality deliver'd in the very best Language»: it was only corrupt Christian priests who had compromised the text. As Mary noted, «I have since heard impartial Christians speak of it in the same manner, and I don't doubt that but all our translations are from Copys got from the Greek Preists, who would not fail to falsify it with the extremity of Malice». Reflecting on the historical obscurity of the «first institution» of religious foundations and the diversity prompted by subsequent clerical «interpretations», Lady Mary could not forbear to note «the natural inclination of Mankind to make Mysterys and Noveltys». The variety of Muslim sects matched those in Christianity, certainly they were «all equally zealous against each other». Scrutiny of elite beliefs suggested that «plain deism» was the prevailing opinion; Achmet-Beg, knowingly gesturing at Rycaut's account, refuted that any denied the existence of God. Far from being atheists «their impiety consists in making a jest of their prophet». Here it is possible to see a practical comparison of religious institutions and texts developing from personal intimacy. ${ }^{41}$

The contemporary Islamic world was also aware of intellectual developments in the West. Indeed, although it has not been noted before - Lady Mary's meeting with Effendi Achmet-Beg establish-

40 See for an overview Matar, N.I., "Islam in Britain, 1689-1750", Journal of British Studies, 47 (2008), 284-300; and idem, "The Last Moors: Maghāriba in Early EighteenthCentury Britain", Journal of Islamic Studies, 14 (2003), 37-58.

${ }^{41}$ Grundy, I., Lady Mary Wortley Montague. A comet of the Enlightenment, Oxford, 1999, 134-136, 144, 148, 156. 
es that even as far away as Belgrade there was interest in English debates. No stranger to the party politics of early eighteenth century England, Lady Mary noted that he also «seem'd to have some knowledge of our Religious disputes, and even of our writers». Indeed she had recommended the religious views of Samuel Clarke (vilified by many Arian heretic) and William Whiston (honest Newtonian) - after comparing the two creeds she suggested there was little difference in common notions. More significantly, she continued to note that «I was surpris'd to hear him ask, among other things, How Mr Toland did?». ${ }^{42}$ The fact that Lady Mary was known to Toland through her friendship with Mary Monck, daughter of the Irishman's friend and patron Lord Molesworth, suggests the unrecorded elements of their conversation may have touched upon Islamo-Christian relations. As will be discussed, the example of Toland's Nazarenus allows an exploration of how some Islamic traditions were appropriated and radicalised by freethinkers in the period.

In an earlier, and more explicit letter, Lady Mary had suggested that most of the learned religious men «had no more faith in the inspiration of Mahomet, than in the infallibility of the Pope. They make a frank profession of Deism among themselves, or to those they can trust: and never speak of their Law but as of a politick institution, fit now to be observ'd by wise men, however first introduc'd by Politicians and Enthusiasts». ${ }^{43}$ Lady Mary's friendly effendi outlined some of the standard Islamic objections to Christianity -its image worship, absurdities like transubstantiation and mariolatry (interestingly, no mention was made of the Trinity). Lady Mary's most recent biographer has suggested these encounters prompted «her mission as defender of Islam against Christian prejudice». ${ }^{44}$ Drawing from this comparative vein such Muslim antiChristian arguments contributed to the staple freethinking critique of organised religion in the West.

Further contexts for examining the process of reception and encounter that may have shaped Hornby's ownership of the manu-

${ }^{42}$ Halsband, R.(ed.), The complete letters of Lady Mary Wortley Montague, Oxford, 1965-1967, 456.

43 "Letters during the embassy to Constantinople", The complete letters, 108-109, April $1^{\text {st }}$ 1718; see also 317-320; and the letter to Conti, Feb. 1718 at 456.

${ }^{44}$ Grundy, Lady Mary, 136. 
script can be seen in the work of men like Pierre Bayle. Writing in the Pensées (addressing the question of the motivation and reputation men like the renaissance unbeliever Vanini who had been martyred for being atheists), Bayle commented on a recent case of «a certain Mahomet Effendi who was executed in Constantinople not so very long ago for having made known his beliefs denying the existence of God». As Bayle noted, like Vanini, Mahomet Effendi had declined the opportunity to save his life through renouncing his error. Instead, persisting in his blasphemies he was reported to have stated that «although he has no reward to expect, the love of truth obliged him to suffer martyrdom in support of it». ${ }^{45}$ Like many in the period Bayle's encounter with Islam was primarily textual. As is widely known, Bayle derived his account of this episode from Paul Rycaut's frequently reprinted history of the Ottoman empire, first published in England in 1668. This work was useful because it surveyed the various Islamic traditions to establish that, like Christianity, there was a diversity of belief under the carapace of uniformity. Just as Christianity showed contemporary fragmentation so did Islam: consequently he gave «an account how busie these Modern times have been at Constantinople in hammering out strange forms and chimera's of Religion, the better to acquit England from the accusation of being the most subject to religious innovations, the world attributing much thereof to the Air and constitution of its Climate». ${ }^{46}$ The evidence of Mahomet Effendi's irreligious beliefs («a rich man, educated in the knowledge of the Eastern Learning») confirmed the natural tendency of all religions to degenerate into heterodoxy. Constantinople was, perhaps like London, a mixture of devout and ungodly. Such examples established that, as Rycaut, pondered «I never could believe that there was a formal Atheism in the World, concluding that the principle (of the being of a God) was demonstrable by the Light of Nature; but it is evident now how far some men have extinguished this light and lamp in their Souls». ${ }^{47}$ The consequences of reading such accounts exposed common themes to the critical mind - religious institutions were liable to

${ }^{45}$ Bayle, P., Various thoughts on the occasion of a comet, R. Bartlett (ed.), Albany, 2000, §182, 228.

${ }^{46}$ Rycaut, P., The present state of the Ottoman Empire, London, 1668, 127.

${ }^{47}$ Idem, The Turkish history from the original of that nation, to the growth of the Ottoman Empire, London, 1687, Book 2, chapter 12, 65.

Al-Qanțara (AQ) XXXI 2, julio-diciembre 2010, pp. 443-480 ISSN 0211-3589 
corruption by churchmen; doctrines might be distorted; moral virtue might operate independently of confessional identity.

The comments of both Bayle and Lady Mary (herself an annotator of Bayle's works) on traditions of contemporary Islamic freethinking and heterodoxy are useful contexts for exploring Hornby's text. They establish the types of cultural and intellectual exchange between Orient and Occident in the period, and present the textual evidence for such exchange. Works like Rycaut's were the result of personal intimacy derived from his position as private secretary for the Levant Company in Constantinople, mediated through a combination of essentially medieval «orientalist» understandings of Islam and the more recent explorations of renaissance scholarship. These real relationships forged over the course of the seventeenth century between consuls, travellers, diplomats and clergymen laid the ground works both for the intellectual encounter, but also very often for the material collections that provided the textual resources for subsequent unforeseen encounters and usages. Somehow the work that ended up translated in Hornby's manuscript had travelled along these networks of exchange and encounter.

Early modern representations of Islam were framed by an assumption of «imposture», but despite this discursive hostility «knowledge» about Muslim history, religion and culture became more sophisticated. The foundations of this knowledge was the accrual of archives of oriental materials driven initially by the Royal Instruction churchman William Laud extracted from the Turkey Company in 1634. The insistence that each ship returning from the East should deliver a Persian and Arabic manuscript for the nation, ultimately created manuscript collections in Oxford libraries which became sources for later figures like Edward Pococke (sometime chaplain to the Levant Company at Aleppo) to execute scholarly editions with. The works of erudition themselves subsequently (through print dissemination) further broadcast the Arabic sources widening the possibilities of encounter by extending the potential audience. ${ }^{48}$ So, for example, Bayle's construction of the image of

48 Trevor-Roper, H., Archibishop Laud, 1573-1645, London, 1940, 274, 282-83; Feingold, M., "Patrons and professors: the origins and motives for the endowment of university chairs - in particular the Laudian professorship of Arabic", in Russell, The 'arabick' interest, 109-27. 
Islam was made by skilful use of works like Rycaut's (and indeed of a range of other standard works in his other writings on Islam most obviously in the Dictionnaire) rather than any sort of direct engagement with «original» sources. By the end of the seventeenth century literate men and women had a significant and serious corpus of potential resources at their disposal to develop a better informed view of the nature of Islamic religious practices and beliefs, accounts of Arabic historical traditions, and even perhaps to acquire the linguistic skills to pursue their own enquiries. This is not to suggest that the encounter with the "Orient», was either unprejudiced, tolerant or necessarily constructive. Translations of the Qur'ān, scholarly histories of the life and times of the Prophet and the Arabic nations, and commentaries on theological works were all inevitably shaped by the confessional priority of defending Christian doctrinal integrity. The most popular English language work of the period was Humphrey Prideaux's Life of Mahomet (London, 1697), the subtitle of which — «the true nature of imposture»- establishes its polemical objective. This work became a standard resource well into the third decade of the eighteenth century, claiming to deliver an impartial and «matter of fact» account while actually exploiting traditional «orientalist» discourses to besmirch contemporary Christian dissidents with charges of imposture and deceit. It was precisely the sort of book Hornby would have no doubt been very familiar with.

Prideaux's work captures the ambiguous reception of Islamic and Arabic ideas and texts in the «orientalist» discourses of the period. Conceived as an explicit defence of Trinitarian doctrines and the «Hypostatical Union», the work was also concerned to establish its credentials as a work of erudition. For example, it proudly outlined an understanding of Arabic transliteration, naming practices and a collection of authentic sources. Prideaux noted that the common usage of referring to «Mahomet» was incorrect: «Mohammed be the alone true and proper pronunciation of the name». ${ }^{49}$ His claim to expertise was reinforced by appending «An account of the Authors quoted in this Book», which ran to some 27 pages, describing the corpus of learning he had used. This list included Arabic sources (Abul Faraghius, Abul Feda, Agar, Al Bochari, Al Gazali

${ }^{49}$ Prideaux, H., Life of Mahomet, London, 1697, xii.

Al-Qanțara (AQ) XXXI 2, julio-diciembre 2010, pp. 443-480 ISSN 0211-3589 
etc.) compilations, editions of the Qur'ān, dictionaries and chronicles - as well as Hebrew, Chaldee, Greek, Latin and French works. ${ }^{50}$

Despite these explicit and deliberate claims to a capacious and state-of-the-art scholarly erudition, Prideaux's linguistic skills and oriental learning were not all they appeared. The extended bibliography he cited, included virtually the entire canon of early modern orientalist scholarship: Andreas, Hottinger, Golius, Sionita, Erpenius, Bibliander and perhaps most significantly, Edward Pococke (the «greatest ornament of the age») whose Specimen Historial Arabum was described as «a most accurate and judicious collection out of the best Arab writers». It was of course important to the credibility of his own writing that Prideaux was seen to be expert in these matters: it seems clear that he cribbed nearly all of his «references» out of these modern commentaries. Certainly the judgement of Peter Holt confirms this, «upon examination [...] it becomes clear that his knowledge of them was derived at secondhand, from translations or quotation in the works of orientalists». ${ }^{51}$ The plausibility and evident effectiveness of this literary ruse of claiming to be using original sources allows an insight into the possibilities of appropriation offered by these Islamic sources. Orientalist writings delivered access to a tradition of writing and thinking about religion which potentially clashed with Christian orthodoxies. The theological motivation which underpinned orientalist scholarship contrived to fix the representation of Islamic history as hazardous and impious: readers had to work hard to derive effective exemplars from the East to turn against orthodoxy. As Hornby's manuscript establishes there were alternative uses for the significance of Islam rather than the traditional denigration of imposture.

The cultural and social institutions which underpinned «the republic of letters» established a network of communications linking knowledge of the East to communities in the West. Prideaux's appendix was the end product of such circulation of oriental scholarship. As this erudition moved around scholarly communities in Europe it created authoritative texts for citation and credible testimony.

${ }^{50}$ Ibid., 259-286.

${ }^{51}$ Prideaux, Life of Mahomet, 284-85. See Holt, P.M., "Early Students of Arab History in England", in Studies in the history of the Near East, London, 1971, 49, 52. 
Evidence of this circulation of learning is most apparent in the dense inter-textuality of many of the most significant works which Prideaux used. The learning in Marracci's Prodromus was derived with full acknowledgment from the volumes of Pococke and Hottinger. George Sale's later edition of the Qur'ān borrowed intensively and explicitly from Marracci's texts. ${ }^{52}$ It is possible to show how this cycle of transmission, reception, revision and re-use was prompted by Pococke's initial contact with «original» Arabic sources through his friendship with al-Darwīsh Ahmad, a Syrian Muslim who acted both as an agent and copyist. Substantial archives of oriental manuscripts were the material results of this sort of interaction. Pococke used some 70 manuscripts and compendia in preparing his works. Other scholars like Erpenius and Selden also accumulated substantial collections which later became resources for other scholars in the universities. ${ }^{53}$ These consisted of collections of Quranic commentaries, astronomy, hadith, law, lexicography, and biographical volumes. ${ }^{54}$ These archives, themselves the material product of many individual cultural encounters, became available for a variety of intellectual and theological projects. Subsequently and significantly Pococke's printed volumes communicated these sources in more digestible forms to many other audiences. Collectively such orientalist works, as Alastair Hamilton has explained, produced «a vast and learned commentary [which] [...] initiated a truly informed study of Islam». ${ }^{55}$ Even as some less erudite works like Andre du Ryer's introductory «Sommaire» to his edition of the Qur'ān, perpetuated the misunderstandings of traditional Christian accounts of Islamic religion (for example, treating ritual washing as a form of ablution, and circumcision as sacrament) it also used the best and most learned Islamic commentaries (tafsir $)$ from the eleventh century onwards. ${ }^{56}$ Less orthodox readers like

52 See for example, Denison Ross, E., "Ludovico Marracci", BSOAS, 2 (1921), 117 123 , which points out that much of Marracci's account was derived from the works of Pococke and Hottinger.

${ }^{53}$ Holt, P.M., "The study of Arabic Historians in seventeenth century England: the background and work of Edward Pococke", BSOAS, 19 (1957), 444-455.

${ }^{54}$ Wakefield, C. "Arabic Mss in the Bodleian Library: the seventeenth century collection”, in Russell, The 'Arabick' interest, 128-146.

${ }_{55}$ Hamilton, A. and Richard, F., André du Ryer and oriental studies in seventeenth century France, Oxford, 2004, 13.

${ }_{56}$ Ibid., 94-96. 
Stubbe were capable of mediating these traditions for their own purposes: Hornby's ownership of Stubbe's manuscript suggests there was an audience for such material.

There were a number of possibilities for how this sort of textual tradition might be appropriated. Pious authors like the late seventeenth century antitrinitarians sought opportunity to exploit the monotheist traditions of Islam as a mirror for theological prescription and good practice. In this process, sincere theologians saw some (to their minds) real co-incidence between the Islamic religion and their own understanding of the «true» Christian faith. This use of Islam can be sharply distinguished from the more controversial but perhaps less earnest, exploitation of a more fundamental set of anticlerical arguments found in Islamic anti-Christian polemic. Many Islamic texts denounced the Christian clergy for «selling absolutions, transgressing the laws they impose on other, ignorance, and self serving use of excommunication». ${ }^{57}$ Men like Stubbe and Toland, saw here a broader opportunity for comparing irrational Christian tradition with rational Islam. But first they had to have understood the Islamic perspective. Stubbe's Account grew out of the milieu of Oxford erudition of the late 1650s when he had especially privileged access to the collections as Deputy Keeper of the Bodleian Library. Moving in some of the same circles as Pococke, like subsequent writers, he exploited a wide range of learning to make authoritative arguments, expertly detaching the evidence from any accompanying pious commentary to underpin his heterodox points. Both Stubbe and Prideaux used the same erudition (in many cases in the same volumes) but did so to very different conclusions.

The historical account of Stubbe's work has been derived from the 1911 printed edition. Despite reproducing the main body of the text this edition did not provide the marginal annotations of the two extant scribal versions held in the British Library which allows insight into the erudition exploited in the work. ${ }^{58}$ A survey of these citations establishes that Stubbe drew from a range of Biblical, patristic and oriental writings. A simple count of the references to

${ }^{57}$ Lazarus-Yafeh, H., "Some neglected aspects of medieval Muslim polemics against Christianity", Harvard Theological Review, 89 (1996), 61-84, esp. 73.

${ }^{58}$ British Library, Harleian 1876, "An account of the Life of Mahomet", and BL. Harleian 6189, "The Rise and Progress of Mahometanism". 
identified works, while an unsubtle tool which does not capture the number, precision and variety of multiple page references to passages, does expose significant general patterns. Commonly citations of «original» sources like «Elmacin», «Maimonides», or «Gregor. Abul-farai» were often noted as being «apud Hottinger», or from Pococke's work. Stubbe uses the «voice» of Arabic sources in an explicit and positive manner, but in almost every instance this material was mediated by the scholarly conventions of early modern editors. As the distribution of citations suggests, works of continental and English scholarship by Casaubon, Grotius, Selden, Salmasius, Buxtorf, Vossius and Lightfoot were all repeatedly used for accounts of Jewish and early Christian practice and doctrine. The dominant orientalist works used were three -Edward Pococke, Johannes Hottinger and John Selden, although books by Thomas Erpenius, Gabriel Sionita and Paul Rycaut were referenced as well as standard editions of other «primary» texts. ${ }^{59}$

The presentation of these oriental sources was framed by pious Christian discourse. Stubbe managed to detach this shell of piety from the erudition. Evidence of how he did this can be seen in the unusual, and essentially anti-Pauline, account of the early Christian Church which rested on a standard work of Islamic polemic, derived from Hottinger's Historia Orientalis (1650). ${ }^{60}$ It is worth reproducing the first comment from Stubbe in full:

I remember a Mahometan story of Ahmed ben Edris, that Paul instructed three Princes in religion, and taught each of them a different Christianity: assuring each of them singly that he was in the truth, and that afterwards when Paul was dead, each of them pretended his religion to be the true religion derived from Paul, whence arose great feuds amongst them.

This was expanded (from the same source) a few folios later into a specific account of anti-Pauline heresy:

And Ahmed ben Edris, passing over the Nestorians as a foolish sort of Christian Hereticks, brings in a fable concerning Paul, as if he had deluded the World into an opinion of the Deity of Isa, and given a beginning to the Heresy of Eutychius and the Jacobites. And that an Arrian or else a Judaising Chris-

59 There were some 288 citations: Hottinger 36 (13\%); Pococke 56 (19\%); Salmasius $15(5 \%)$; and Selden $34(12 \%)$ were the most frequently acknowledged.

${ }^{60}$ Hottinger, J.H., Historia orientalis, Tiguri, 1651, cited here in a 1660 edition.

Al-Qanțara (AQ) XXXI 2, julio-diciembre 2010, pp. 443-480 ISSN 0211-3589 
tian whom he calls an Elmunin (Al Momin), or true beleiver, did anathematise Paul thereupon, saying, We were the Companions of Isa; we saw him; we are descended from him; he was the servant and Apostle of God; he never told us otherwise. And the same Author further tells us that Mahomet met with thirty of the descendants of this Elmunin or orthodox person, who were retired into an Hermitage, and that they owned his Doctrine and profess'd Moslemism. ${ }^{61}$

Stubbe's conclusions were blunt if bold, «This that I have said I hope is sufficient to evince that the Religion of Mahomet is cheifly founded on the Doctrines of the Nazarene Christians and the Arrians». Here he cited «Ahmed ben Edris» to underpin the backbone of the heterodox account of the relationship between Christianity and Islam. How he executed this is worth exploring in detail.

Stubbe extracted a narrow range of passages from Hottinger (overwhelmingly from Book 2 chapters 1 to 5) which provided details of pre-Islamic «Sabean» traditions as well as specific quotations from Muslim texts. Stubbe acknowledged that Hottinger had «taken the pains to transcribe a great many of their precepts out of the books of the Mahometans». ${ }^{62}$ Hottinger's intention had been to reconstruct the «superstition» of the Chaldees and «de statu christianorum $\&$ judaeorum tempore orti $\&$ nati muhammedismi». To that end he had used various "compendia historia» to describe the Prophet's education and journeys into Syria. Amongst these were noted «Elmacino», «Abunazarus» and «Ahmed Ibn-Edris» (the latter described by Hottinger as «in virulento suo scripto contra Judaeos \& Christianos»). ${ }^{63}$ In chapter 2, Hottinger explored the connections between early Christian heresy and Islam. ${ }^{64}$ Supplementing typical patristic sources - Eusebius, Marcellinus, Sozomen - to give accounts of the Collyrydian, Jacobite and Nestorian beliefs, Hottinger extracted material from «Fabula Ahmed Ibn-Edris de tribus his sectis». Presented in both Arabic script and Latin translation the passages recounted the description of a Nazarene gospel — «evangelium quintum»- which Hottinger unambiguously dismissed as apocryphal and «fabulosos». Throughout the chapter Hottinger presented, reviewed and eliminat-

61 Stubbe, An Account, fols. 31 and 37 citing "Hottinger hist. or. 1. 2. c. 2". See van Koningsveld, P.S., "The Islamic image of Paul and the origin of the Gospel of Barnabas", JSAI, 20 (1997), 200-228.

62 Stubbe, An Account, fol. 40v.

63 Hottinger, Historia Orientalis, 309, 318.

64 Ibid., 320-361.

Al-Qanțara (AQ) XXXI 2, julio-diciembre 2010, pp. 443-480 ISSN 0211-3589 
ed, claims (sourced from «Ah. Ben Edr») about suppositious infancy gospels of «Nazareni» as imposture. By triangulating material from Epiphanius (on the Ebionites and Nazarenes) with accounts (from Elmancinus and Beidawi) of the Collyridean beliefs about Mary and the Trinity (insisting that there were three Godheads - «Maria», «Isa», and «Deus»). Hottinger confirmed that Islam was contaminated by an heretical Nestorian Christianity. Hottinger used his Islamic sources — «Ahmed ben Edris»- to establish this impious antiPauline account of early Christianity. ${ }^{65}$

Stubbe's reading of Hottinger allowed him to detach the critic's pejorative and hostile view of these Muslim anti-Christian polemics from the arguments themselves. As noted above, Hottinger regarded Ahmed ben Edris as an antagonistic and aggressive voice - «in virulento suo scripto contra Judaeos \& Christianos»: Stubbe reproduces the original language unframed by pious anxiety. Muslim narratives are presented as authoritative fact condemning the corruption of Pauline Christianity: this allowed the case to be made for a connection between a primitive non-Trinitarian Ebionism and the foundations of Islam. Stubbe was unhesitant in using Arabic sources to present a less prejudiced account of Islamic beliefs and practices: for example, his account of the status of the Qur'ān was derived from respectable Muslim sources. As these learned Muslim commentators confirmed, the Qur'ān was revealed and perfect, "Thus say Beidavi \& Ahmed Ben Edris. Alguazel tells us to this purpose, that the Coran is a transcendent Miracle». ${ }^{66}$ Again these views were extracted from Hottinger and Pococke rather than directly from the Muslim works themselves. Stubbe's manuscript work not only outlined a method for exploiting Islamic sources to heterodox purpose, but also some very specific textual examples.

Others in the clandestine world of letters in the period also saw such opportunities. The classic example of this is the work published under the title of Four treatises concerning the doctrine, discipline and worship of the Mahometans (London, 1712). ${ }^{67}$ Printed

65 «Paulum ex persecutore factum esse Christianismi lumen \& columen, Trinitatis clarissimum doctorem, fortissumumque hyperaspisten», Hottinger, Historia Orientalis, 350 .

${ }^{66}$ Stubbe, An Account, fol. 48r.

67 The first two parts of this work were translations of De religione mohammedica libri duo published at Utrecht in 1705 which drew from translations of passages from Abū 
out of the recognisably Whiggish publishing stable of John Darby the work brought together Dutch, English and French erudition. It did so, arguably, to heterodox purpose. Combined with translations of Adrian Relaant's commentaries on Arabic sources, and Thomas Hyde's work on the Turkish Liturgy, was a translation from the long French essay of Mathurin Veyssière de La Croze (Royal Librarian at Berlin) titled «Reflexions historiques et critiques sur le mahometisme, et sur le socinianisme». ${ }^{68}$ La Croze's Dissertations historiques sur divers sujets (published originally at Rotterdam by Reinier Leers in 1707) had contained not only the essay on Islam and Socinianism, but also studies of the criticism of Pere Hardouin, and historical inquiries «sur l'etat ancien et moderne de la religion chretienne dans les Indes». ${ }^{69}$ For our purposes, La Croze's historical reflections on the relationship between Islam and Socinianism is of interest, not for its substantive claims about the convergences between the two religious dispositions, but for its use of specific Islamic sources.

La Croze was a learned man with an unusual and impressive range of linguistic skills, nevertheless he exploited the standard canon of oriental erudition to construct his accounts. Edward Pococke's work is referenced («Notis ad spec. Histor. Arab») frequently; alGazālī's works, described as «a very large explication of the Mussulmans confession of Faith», are regularly used; the writings of Elmacin and Beidawi are quoted from occidental commentaries like Hottinger, Reland and Marracci; various editions of the Qur'àn, most notably by Hinckelman and Du Ryer, are examined. There are two significant passages. First, following a discussion of Muslim accusations of scriptural corruption (tahriff) and its similarity to the assault mounted by Socinians, La Croze noted, «the Mahometans have wrote a great many books of controversy against the Christian

Shujā, Ahmad b. al-Husayn al-Isfahānī, b. 434/1042-3; the third part was a translation from the Latin Tractus Alberti Bovovii [...] de Turcorum liturgia, Oxford, 1690, edited and annotated by Thomas Hyde.

${ }^{68}$ Israel, Enlightenment contested, 129-131.

${ }^{69}$ La Croze's later work, Entretiens sur divers sujet d'histoire, de litterature, de religion, et de critique, (Cologne,1711), was written in the form of four conversations between a Christian and a Jew. A later edition was published in London (1770), Entretiens sur divers sujets d'histoire et de religion entre Mylord Bolingbroke et Isaac D'Orabio, Rabin des Juifs portugais à Amsterdam. Michel de la Roche's Memoirs of literature, London, 1712, reviewed this work in detail 173-179. 
religion». As a means to oppose such «polemical books» he included some «extracts», in particular from «Ahmet Ben Abdala» - the very work reproduced in Hornby's manuscript. The four passages were explicitly copied from Grapius's Rostock edition (1705). A comparison of the opening passages with the text of MS 537 suggests a different translator was at work: the four short paragraphs include the introductory question, a statement of God's unity, the da $w a$ or pronouncement of the six articles of faith, and a comment on the nature of human understanding. La Croze concludes his reflections on the work by suggesting that the Muslim account of God was closer to the truth than the Unitarian, «in the Articles of the Creation, of the knowledge of God, of Providence, of Predestination, and of the state of Human souls after Death». Here the citation of the Islamic source is designed to expose similarities with Socinian arguments, but simultaneously to valorise the status of the text. ${ }^{70}$ La Croze, arguably, exploited his materials in a similar vein to Stubbe and Hornby.

The second citation of Ahmed ben Edris (added to a discussion of Julian the Apostate's applause for the Arian heresy) used the same passages quoted by Stubbe. La Croze simply stated, «Ahmed ben Edris, a Mahometan Divine, who some ages ago wrote a Book of Controversy against the Christians, accuses St. Paul, in a fabulous narration, full of ridiculous circumstances, of having introduc'd the Doctrine of the Trinity into the Christian Religion». ${ }^{71}$ Clearly quoting from a source he does not acknowledge, La Croze rehearsed Ahmed Ben Edris' views of Paul having four disciples (Jacob, Nestorius, Melchites, and Orthodox). The first three sects persecuted the last for only acknowledging in Christ «the quality of Prophet and Ambassador of God» who thus were exiled into the deserts of

${ }^{70}$ Compare La Croze, M.V. de, "Historical and Critical Reflections upon Socinianism and Mahometanism", in Four Treatises Concerning the Doctrine, Discipline and Worship of the Mahometans, London, 1712, 184-187, and SH Ms 537, fols. 1-3. The last passage, «no human understanding can perceive or comprehend, that the Father, son and holy ghost are at the same time, and in the same essence, one and the same God; and the omnipotent God never requir'd nor commanded man to believe what can neither be perceiv'd nor understood. On the contrary, he hath given Man an understanding apt to conceive whatever was possible and necessary, and to deny and not conceive what is impossible», might be read as a summary of the contemporary arguments of men like Toland against the «mystery» of the Trinity.

${ }^{71}$ La Croze, "Historical and Critical Reflections", 206-207. 
Syria. As the work continues: "This sect, continues Ahmed, subsisted till the time of Mahomet's mission; and thirty of them being inform'd concerning the Mahometan Religion, immediately embrac'd it». Speculating that Ahmed's account was distorted by partiality and the standard practice of Arabic «compilations», La Croze drew a specific connection with the early Judaeo-Christian sect: «we may conclude», he insisted, "that the thirty persons, whom, Ahmed speaks of, were the remains of the Ebionites, who without any difficulty, embrac'd the Doctrines of the false Prophet, who reviv'd opinions perfectly like their own». ${ }^{72} \mathrm{La}$ Croze shares common themes with Stubbe. Both works suggested that the state of pre-Islamic Arabia religious beliefs (identified with the «Sabeans») prepared the way for subsequent «revolutions» and «imposture». ${ }^{73}$ The same material was used in Bayle's Historical Dictionary in the lengthy entry on «Mahomet». Bayle noted, «But I must observe, bye the bye, that the Mahometan Religion is not so destitute of Apologists as is commonly believ'd». Such apologists not only wrote «in favour of the Alcoran», but more importantly, "against the Bible, with great pains and skill; to foment prejudices». Using exactly the same passages that Stubbe had exploited, he continued to note, «Hottinger speaks of an author who has laid open the apparent contradictions of the Bible, and pretends to prove the mission of Mahomet even from that book». Note (g) identified this author: «He is call'd Ahmed Abulabbas, Ben Edris Sanhaghius, Melkita. See Hotting. ubi supra, $p$. 337».${ }^{74}$ Here we can see the same orientalist source providing substance for a variety of heterodox projects. Toland's Nazarenus is perhaps the most subtle and deceptive of these re-workings of traditional scholarship (both patristic and oriental).

These sources are at play in Toland's projection of connections between the three Abrahamic religions made in Nazarenus published first in 1718 (but in circulation amongst heterodox circles around Eugene of Savoy as early as 1709). ${ }^{75}$ Nazarenus was notorious amongst learned audiences in Europe for advancing the canonical

${ }^{72}$ Ibid., 207.

73 Ibid., 168.

${ }^{74}$ Bayle, P., An Historical and Critical Dictionary, London, 1710, 2103.

${ }^{75}$ Champion(ed.), Nazarenus. 
claims of the Gospel of Barnabas. This fifth gospel, Toland claimed, established a number of unusual truths; first, that Islam and Christianity shared a potential common scriptural heritage (distinct from the corrupted canon), and second, that the two religions were historically joined by the evidence of a sect of early Judaeo-Christians known as Ebionites or Nazarens. ${ }^{76}$ Much of the polemical radicalism of this case was derived from an encounter and appropriation of Islamic anti-Christian writings - in particular, from a reading of Islamic medieval sources Toland may only have been capable of examining in erudite Orientalist sources. Although he had access to a range of books on Islamic traditions it was the encounter with a manuscript version of the Gospel of Barnabas which provided the opportunity for establishing a common thread («the original plan of Christianity») between Judaism, Christianity and Islam. ${ }^{77}$ In a passage of erudition he deliberately added to the original French language manuscript composed for Eugene of Savoy, Toland reviewed the evidence of Muslim knowledge of the sayings of Christ (citing works by the Dutch scholar Levinus Warner and an Islamic source by Kesseus) suggesting that these were drawn not simply from apocryphal scripture but from a fifth gospel. ${ }^{78}$ This was not to be confused with the Arabic infancy gospel edited by Henry Sike (published in 1697, but included in Johann Albertus Fabricius' collection of New Testament apocrypha) which could be dismissed as «long anterior to MAHOMET» because of its invocation of the Trinity. Toland noted a more accurate account of Muslim views of

\footnotetext{
${ }^{76}$ Toland's claim has wielded a bewitching influence over modern scholarship. For example, writing of the Ebionites as «descendants of the primitive Jerusalem community» the patristic scholar H.J. Schoeps, concluded that as far as their «religious teaching and doctrinal formulation are concerned, these, more or less modified and recast, again came to the light of day - along several lines of connection - in the third, and up to the present time last revealed, religion in world-history, Islam». See Schoeps, H.J., "Ebionite Christianity", Journal of Theological Studies, 4 (1953), 219-224, 224.

${ }^{77}$ For Toland's ownership of such books see Champion (ed.), Nazarenus, 306, listing «Ricoldus, et alia Mahomedica. Prideaux's Life of Mahomet»; 311, listing «Reland de Rel. Mahomedica».

${ }^{78}$ See also Stubbe, An Account: «As for the Arrians it is manifest that the Saracens have alwaies retained a veneration for their St. George, Bishop of Alexandria, whom yet they do not allow for a Prophet, but one of their Saints or Fathers, and his Life is written by Kesseus, a Mahometan, as if he were such», fol. 35r, which cites Hottinger as the source. Toland identifies him in a footnote as "Abu-Mohammed Abd-Alla». Also cited in 1712 Four treatises, Book 1, "A short system", 39.
} 
Christian scripture: «They are not ignorant however, either of the existence or imposture of the just mention'd Gospel of the Infancy, which Ahmed eBn Edris cites by name, calling it also the fifth Gospel (as you may see in the 2nd chapter of the first part of MARACCI's Prodromus) but redundant, says he, in many things, and in many things defective». ${ }^{79}$ Interestingly, here Toland does not cite directly the classic orientalist sources, but invokes the more contemporary Ludovico Marracci whose edition of the Qur'ān had been published with an hostile commentary (the Prodromus) in 1698. As noted above, Marracci's work drew from the common scholarly corpus of Hottinger and Pococke. ${ }^{80}$

As the evidence of Toland's book establishes - he had plundered the canon of up to date patristic learning to reconstruct the diverse sectarian nature of the early Church, but in effect he did little more than rework the general argument of similar passages in Stubbe's «Account». Whereas the earlier work attempted to establish a thread of connection between early Christian monotheism and Islamic theology by implication from various apocryphal scripture -Toland argued for an explicit connection with the «discovery» of the Gospel of Barnabas. As he explained, «the Mahometans not only believe, as is well known, many things recorded of Jesus in our Gospels; but that they have likewise a peculiar Gospel of their own, tho probably in a few hands among the learned, from which perhaps some passages in ours may be farther illustrated». ${ }^{81}$ The point of this appropriation was complex. Some readers of Nazarenus were convinced of the sincerity of these putative claims about the precise historical connections between Judaism, Christianity and Islam. Others were (probably correctly) fundamentally suspicious about Toland's heterodox intentions: the view of religious institutions underpinning Nazarenus challenged commonplace conceptions of revealed truth.

The radical engagement with the corpus of Arabic writings was utilitarian. As has been traced above - Stubbe, Toland, La Croze and Bayle frequently cited from a common pool of Islamic sources

79 Toland, J., Nazarenus, or Jewish, Gentile and Mahometan Christianity, London, 1718, 20-21; Champion (ed.), Nazarenus, 147-148.

${ }^{80}$ Marracci, L., Prodromus ad refutationem Alcorani, Patavii, 1698, Part 1, chapter 2, 12, citing «Ahemedus ebn edrisus» on the Arabic infancy Gospel.

81 Toland, Nazarenus, 21; Champion (ed.), Nazarenus, 148. 
derived from mainstream Christian erudition. These archival fragments became controversial in impious hands. The polemical value of these texts can be explored by considering them in their first context of late twelfth century anti-Christian disputes. "Ahmed ben Edris» was Shihāb al-Dīn Muhammad b. Idrīs al-Shāfi'ī or al-Qarāfî (d. 684/1285), a māliki scholar based in Mamluk Egypt, described as the greatest jurisprudential mind of the thirteenth century. Sherman Jackson noting that «western scholarship to date has taken only short notice of al-Qarafi» argues that his theological writings were the "greatest apologetic achievement in Islam». ${ }^{82}$ A late eighteenth century biographical dictionary simply recorded, «He is the author of the book intituled Agiubat al fakherah an alilat al faferah: an answer to the questions and difficulties proposed by the Jews and by the Christians against Mohammedanism». ${ }^{83}$ Like the «Epistle» in Hornby's possession, al-Qarāfî's anti-Christian polemic promoted an intransigent monotheism coupled with a call for Christians to return to a pure and original religion.

The critique refuted Christian claims for the authenticity and textual integrity of scriptural revelation, the doctrine of the Trinity and associated positions (substance, person, nature of Christ), and the occlusion of the "prophecy» of Muhammad in Scripture. A central theme was that of tahriff - the insistence on the fundamentally false, manipulated and corrupted nature of Old and New Testament scripture. Christian priests had erased the prophecy of Islam from the gospels. By meticulously exposing the contradictions, lacunae, absurdities, and textual corruptions in the received books of Scripture, al-Qarāfī condemned the falsity of Christian belief (in particular the doctrinal deviance of the Trinity). Al-Qarāfî's work, as Bouamama has discussed, was unoriginal drawing on a powerful anti-Christian tradition. ${ }^{84}$ Central was a conviction that the four gospels of the New Testament each gave divergent views of Christ allowing the artifice of «interpretation» to support human interest. Underpinning this was a commonplace argument that Scripture had been subjected to deliberate forgery: the Gospel of John was the

\footnotetext{
${ }^{82}$ Jackson, S.A., Islamic law and the state. The constitutional jurisprudence of Shihāb al-Dīn al Qarāfì, Leiden, 1996, 2.

${ }^{83}$ A new and general biographical dictionary, London, 1798, vol. 3, 321.

${ }^{84}$ See the useful survey of Bouamama, A., La littérature polémique musulmane contre le Christianisme depuis ses origines jusqua'au XIII siècle, Algiers, 1988.
} 
most notorious case. The New Testament was not divine revelation but an human and historical account (possibly derived from a now lost original and authentic gospel). One of al-Qarāfì's primary polemical points was that Christian tradition had manipulated biblical texts. There was plenty of textual evidence of this corruption. God was impiously portrayed with human characteristics. Absurdly, and most obviously, was Moses' account of his own death. The gospels, it could be shown, contradicted each other and therefore could claim no status as revealed knowledge. Furthermore, while much extant scripture was inaccurate, there was also evidence that a variety of other scriptures (infancy gospels were commonly named) had been lost. Al-Qarāfì, like other anti-Christian polemicists, focused on the most apparent difficulties: the contradictions of the various genealogies of Christ were a significant issue. But the language of the Trinity - where an hostility to languages of substance, person, hypostases may have been drawn from Porphery- was also subject to profound criticism. ${ }^{85}$

The anti-Pauline dimension of al-Qarāfì's polemic was present in many twelfth and thirteenth century Islamic works. Such arguments were built out of a genuine confusion between Paul and the heretical reputation of Paul of Samosata (Patriarch of Antioch c. 260). The primary underlying claim was that an originally pure Christianity had been corrupted by the introduction of Trinitarian doctrine, itself the product of Romanising philosophical confusion and the admixture of pagan ideas with Christianity. Al-Qarāfī neatly condensed this theme into an account of how three distinct Christian theologies had been taught to three kings. Here Paul acted as a model impostor: «this cursed Paul was the first one to corrupt the religion of the Christians after they had professed the unity of God. He changed the foundations of their laws and altered the system of their rules concerning circumcision etcetera. He is the origin of the confession of Trinity [which sprang] from his evil view». ${ }^{86}$ Other Islamic anti-Pauline traditions such as that of 'Abd al-Jabbār b. Ahmmad's (c. 995, Tathbìt dalà'il nubuwwat sayyidi-nā Muhammad, «on the signs of Muhammad's prophecy») developed a critique which argued that

${ }^{85}$ Idem, passim.

${ }^{86}$ Van Koningsveld, "The islamic image of Paul"; see also Burrus, V., "Rhetorical stereotypes in the portrait of Paul of Samosata", Vigiliae Christianae, 43 (1989), 215-225. 
Paul had turned Christianity into a form of paganism: «it was not the Romans who became Christians, but the Christians who became Romanised». Premised on an anti-scriptural case it portrayed Paul as a «cunning and roguish Jew [...] a trouble maker and power seeker who employed all kinds of tricks to this end». Employing magic and sleights of hand: "one of their kings suspected Paul, thoroughly investigated his doings, and came to the conclusion that he was a trickster and impostor, whose aim was to gain power». The theme that Christianity had absorbed pagan beliefs and practises was very clear; «it was the Christians who have become Romans and apostasized from the religion of Christ, abandoning root and branch, and adopting the religious practices of his enemies». The Christian Trinity was contrived to appeal to Roman philosophical values. ${ }^{87}$ This was a theme Hobbes developed in his own historical account of early Christianity in the brief work on heresy which Henry Stubbe and Charles Blount were familiar with. The story of Paul revealing secret doctrine to three Christian kings themselves founders of three different Christian sects (Jacob, Nestor, Malkut) was avidly developed by heterodox men like Stubbe and Toland in their accounts of the Gospel of Barnabas and the Nazarenes. ${ }^{88}$ Another anti-Christian polemic written by Muhammad al-Qaysī (a religious scholar of Tunisian origins living in Catalonia) at the beginning of the fourteenth century (Kitāb miftāh al-dīn wa-l-mujādala) also represented Paul as the key figure in the fragmentation, deviation and corruption of Christianity. All of these Islamic traditions asserted a connection with the Gospel of Barnabas. ${ }^{89}$

${ }^{87}$ Stern, S.M., “'Abd al-Jabbār's account of How Christ's religion was falsified by the adoptions of Roman customs", Journal of Theological Studies, 19 (1968), 128-184, 128, 137, 141, 148-149. See also Van Koningsveld, P.S., "The apology of al-Kindi”, in T.L. Hettema and A. Van der Kooij (eds.), Religious polemics in context, Assen, 2004, 69-92.

${ }^{88}$ Stern, "AAbd al-Jabbār's account”, 180-181; Stern, S.M., "Quotations from apocryphal gospels in "Abd al-Jabbār", Journal of Theological Studies, 18 (1967), 34-57.

${ }^{89}$ Van Koningsveld, P.S. and Wiegers, G.A., "The polemical works of Muhammad al-Qaysī (fl. 1309) and their circulation in Arabic and Aljamiado among the Mudejars in the fourteenth century", Al-Qantara, 15 (1994), 163-199. See also Pines, S., "Judaeo-Christian materials in an Arabic Jewish treatise", Proceedings of the American Academy for Jewish Research, 35 (1967), 187-217. I am very grateful to G.A. Wiegers for supplying me with copies of his work on the Islamic tradition and the Gospel of Barnabas: see especially, "Muhammad as the Messiah: a comparison of the polemical works of Juan Alonso with the Gospel of Barnabas", Bibliotheca Orientalis, 52 (1995), 245-291. 
Stubbe and Toland saw opportunities in these works. Combining Islamic traditions with their own readings of patristic sources they argued for continuity between the Ebionites an early Jewish Christian sect (whom they knew of from the pseudo-Clementine sources the Homilies and Recognitions) and the exiled Christian communities of Syria and Transjordan. Connecting Jesus the Messiah with that of the «true prophet» with a profound hostility to Paul's Trinitarianism enabled them to «invent» an historical relationship between Judaism, Christianity and Islam. Other historical material provided further opportunities. The accounts, for example, of debates, disputations and conversations between the three great religions provided texts and arguments which might be exploited for heterodox purpose. Yafeh has pointed to the generation of an heresiographical tradition which was the product of medieval court disputations - especially between Jews and Christians. These works developed arguments about the falsification of scriptures ( $\operatorname{tahriff)}$ which were reused in later polemical exchanges. There is evidence that for example, Jewish antiChristian sources commonly exploited Islamic sources in the late thirteenth century. This sort of polemical exchange also produced a discourse which suggested that Christianity (both its ceremonial and doctrinal traditions) had been the inventions of priests rather than ordained by God: such anticlericalism became a staple of later heterodox thinking. Certainly the specific anti-Pauline emphasis (especially against the Trinity) was attractive to men like Stubbe but the more general argument against the corruption of all priests underpinned a range of eighteenth century polemics. Muslim arguments against corrupt Christian priests very easily became freethinking arguments against priestcraft.

The citation of anti-Christian Muslim polemic like al-Qarāfì (even second-hand via works like Hottinger and Pococke) was not the singular tactic exploited by this heterodox tradition. Clearly texts like Stubbe's «Account» and Toland's Nazarenus accrued authoritative status to themselves by quoting named Islamic sources to a presumably impressed readership. They also absorbed and refashioned some of the key arguments. This is most manifest in the use of standard anti-Christian arguments about the corruption of scripture: in particular the occlusion of New Testament prophecy of the Prophet. Stubbe was explicit in reviewing the evidence of both the Old and New Testaments — «Lastly, whereas Isa says in the Gospel 
(John XVI. 7), Except I go hence, the Comforter will not come to you: but if I depart, I will send him unto you. By the Comforter in this place, they say, is meant Mahomet, the Paraclete or Comforter being one of his names or titles in the Arabian language». Furthermore, continued Stubbe, «before the Gospells were corrupted by the Christians, there were divers passages which made express mention of Mahomet, and were for that reason expunged by them». All of these «unsophisticated Cop[ies] of the Gospel» had been destroyed. ${ }^{90}$ This precise claim was also rehearsed in Toland's work, and Bayle's citation noted the common source in Pococke's work. ${ }^{91}$ It is worth noting that the clandestine Latin manuscript de tribus impostoribus also, amongst a range of comments about Quranic texts, noted that «Moreover, the Mussulmen, from the very books of the New Testament (although according to these very persons, these books have been much corrupted in other respects,) draw various arguments even in support of their Mahomet, and especially that prediction of Christ concerning the future Paraclete. They maintain that he came and exposed the corruption of the Christians, and established a new covenant». ${ }^{92}$ Given the general scepticism of the work, it seems commonsensical to suggest that there was no intention to accredit Muslim critiques of the textual integrity of the New Testament with pious objectives.

One obvious question to pose was why these heterodox authors bothered with working with the Islamic tradition? The challenging technical problems of reading oriental erudition (most obviously linguistic) suggests that the choice to work with these «other» sources must have had specific appeal. Men like Stubbe and Toland had

90 Stubbe, An Account, fol. 50v.

91 «Every traveller almost will tell you, that where JESUS promises to send the Paraclete to complete or perfect all things, the Mahometans maintain the original reading was Periclyte, or the famous and illustrious, which in Arabic is Mohammed: so that their prophet was as much, in their account, foretold by name in the Gospel». Toland, Nazarenus, 13; Bayle, Historical and Critical Dictionary, 2110, on the paraclete «of some Arabian authors, who boast of having read some copies of the Gospel (II), which contained some things concerning Mahomet; which they pretend the Christians have blotted out». Note (II) cites Pococke, Specimen, 185, 186, who in turn gives evidence from Al-Jannabius and Al Selencius (Bar Hebraeus, Specimen historiae Arabum, sive, Gregorii Abul Farajii Malatiensis, De origine \& moribus Arabum succincta narratio: in linguam Latinam conversa, notisque è probatissimis apud ipsos authoribus, fusiùs illustrata, E. Pocockii (opera \& studio), Oxoniae, 1650).

${ }_{92}$ Schroder, De Imposturis religionem, 128, Latin, citing John 14:16.

Al-Qanțara (AQ) XXXI 2, julio-diciembre 2010, pp. 443-480 ISSN 0211-3589 
enough erudition to exploit the standard works in Latin - and indeed to recognise the opportunities for exploiting the findings to their ends. The result of this may be that we need to re-conceptualize the nature of the radical turn as one that was skilled at appropriation rather than invention. The evidence reviewed briefly here suggests that the same fragments of learning could be translated, appropriated and circulated into very different published domains. The brief accounts of the thought of al-Qarāfi, freed from containment in Arabic, was to be found in the works of Pococke, Hottinger, du Ryer and later Marracci and Sale. Once in this comprehensible textual form they were available for reading and usage by a further audience: the fact that these works of erudition were most commonly in Latin also enabled the possibilities of distortion when translated into the vernacular.

The uses of these brief fragments of learning and scholarly commentary open a window onto some general themes. The case for the transmission of a hidden or submerged tradition of materialist, Epicurean and sceptical thought (from pagan antiquity to the enlightenment of the eighteenth century) has recently been restated by a number of historians. The persistence of a philosophical discourse profoundly critical of all forms of organised religion and hostile to clerical imposture is perhaps best illustrated in the reworking of ancient discourses against «superstition» (adeisidaemon) into the radical Enlightenment critique advanced by men like Bayle and Toland. ${ }^{93}$ Much of this historiography has engaged with two distinct processes related to the transmission of ideas. First, there is the business of constructing textual traditions across historical time and geographical space - the material business of copying, editing, translating, publishing and disseminating texts from (for example) Antiquity, from original texts in Greek, Hebrew, Persian, Arabic and Latin, required a complex set of literary skills and resources. Furthermore this process of cultural transmission was also shaped by the propositional content of the ideas contained in the works. Important to this process of determining traditions was the question of

93 See Martin, D.B., Inventing superstition from the Hippocratics to the Christians, Harvard, 2004; and the case made in Champion, J.A.I., "Bayle in the English Enlightenment", in W. Van Bunge and H. Bots (eds.), Pierre Bayle (1647-1706), le philosophe de Rotterdam, Leiden, 2006, 175-96. 
reception and usage: the meaning of many texts was reinvented each time they were redeployed.

The rediscovery of antiquity and the encounter with extra-European cultures in the Renaissance created a textual resource for framing historical and contemporary encounters between Jews and Christians, Pagans and Christians, and Muslims and Christians. The existence of this corpus enabled an innovative literary genre which used alien sources as a means for disputing the legitimacy of domestic practise. The classic post-Renaissance work was Bodin's Colloquium that circulated very widely in Latin and French deep into the eighteenth century which used the device of a learned conversation between figures representing different religious and philosophical confessions to expose orthodoxy. ${ }^{94}$ By the eighteenth century the trope of the foreign commentary exposing the faults of indigenous societies had found a genre form in works like the Turkish Spy and the Persian Letters. Here the exploitation of an exterior perspective to expose the assumptions of the native culture was a shared and recognised literary project. ${ }^{95}$ There was a more complex use of the «other» to critique the domestic —one which proceeded without the explicit (or even informal) acknowledgement of the exotic origins of the source authority. This was a different intellectual project from that embodied in the Persian Letters genre, where the reader was meant to recognise the distance and therefore the polemical purpose of the commentary. This unacknowledged appropriation may simply have been acts of cultural piracy. Many of the examples discussed here betray considerable cultural agility and skill: in order to appropriate an alien text one needed not only to understand its original local intentions (which required technical skills or erudition) but also to recognise the opportunity or potential of contemporary application. This made the activities of men like Toland more than simply acts of intellectual plunder. Reflecting on the literary process at work here may allow a different perspective on some of the more general arguments about the character and trajectory of «Enlightenment» thought. Intellectual innovation seems to have

${ }^{94}$ Doucet, D., Jean Bodin's Colloquium Heptaplomores: clandestine literature, heterodoxy and the possibility of toleration 1590-1750, PhD, London, 2007.

${ }_{95}$ MacLean, G.M. (ed.), Re-orienting the Renaissance: cultural exchanges with the East, New York, 2005. 
been driven by process of appropriation and redeployment rather than the evolution of more sophisticate philosophical rigour. The use of Islamic arguments is a case in point. Men like Stubbe and Toland were not simply exploiting a «better» argument from an Islamic source; but were introducing different perspectives to their audiences. In a relativistic mode the way these «different» sources were invoked, produced a double form of commentary on traditional discourse. Some readers may have recognised that such authorities were «alien», others may not - but the act of citation ensured they were given effectively equal footing with orthodoxy. This raises some interesting questions about the nature of transmission of alien traditions — and the social architecture of knowledge that enabled their consumption. ${ }^{96}$

The relationship between the construction of arguments and descriptions from and about the history of Islam, and the extrapolation of contemporary meaning, was complex. Contrary to the argument advanced by $\mathrm{J}$. Israel, it is possible to see a radical engagement with Islam some half a century before the works of Boulainvilliers and Voltaire. Much of this complexity was driven by (perhaps) deliberately skewed readings of a set of «sources» many of which were available to the learned in the volumes of scholarship produced by orthodox men: the exploitation of works like Hottinger's Historia Orientalis by men as far apart as Prideaux and Stubbe is ample evidence of this deeply contested cultural process. As Charles Hornby read his copy of the two scribal works discussed here - he was absorbing not only a positive theological account of Islam, but also very standard Muslim critiques of central Christian theology. Men like Stubbe and Toland incorporated Islamic arguments into their profane and freethinking discourses from the thread of scholarship created by men like Pococke and Hottinger. Their appropriation of commonplace Islamic attacks on false Christian prophecy and priestly imposture proved particularly effective. The heterodoxy of these acts of cultural translation was the result of calculated intellectual opportunism rather than straightforward importation of freethinking ideas from the original sources. The fact that the Muslim sources used by eighteenth century European Freethinkers were pious and

${ }^{96}$ See Critical Enquiry, 31 (2004), devoted to the "Arts of transmission"; see in particular Blair, "Note Taking as an Art of Transmission", 85-107. 
believing in their indigenous contexts was of little interest to those who used them against the contemporary church $^{97}$. Enlightenment «orientalism» then, at least in this freethinking form, held little respect for either its Islamic subject or its Christian peers - its intention was liberation of not just Europe but the world from the hand of religious oppression. To men like Toland and his ilk erudition was a powerful instrument in the war of ideas against superstition and delusion. Any aspect which advanced this cause irrespective of its «authenticity» or confessional identity was brought to the battle.

Recibido: $02 / 11 / 2009$

Aceptado: 12/02/2010

${ }^{97}$ Stroumsa, S., Freethinkers of Medieval Islam. Ibn al-Rāwandī, Abū Bakr al-Rāzī and their impact on Islamic thought, Leiden, 1999, esp. 21-36.

Al-Qanțara (AQ) XXXI 2, julio-diciembre 2010, pp. 443-480 ISSN 0211-3589 